\title{
Bacterivory by pelagic choreotrichous ciliates in coastal waters of the NW Mediterranean Sea
}

\author{
Evelyn B. Sherr ${ }^{1}$, Fereidoun Rassoulzadegan ${ }^{2}$, Barry F. Sherr ${ }^{1}$ \\ ${ }^{1}$ University of Georgia Marine Institute, Sapelo Island, Georgia 31327, USA \\ ${ }^{2}$ Station Zoologique, B.P. 28, F-06230 Villeiranche-sur-mer, France
}

\begin{abstract}
Ability of natural assemblages of pelagic ciliates to ingest bacteria was tested using fluorescently labeled bacteria (FLB) prepared from in situ bacterioplankton. Ciliate bacterivory was analysed both in freshly collected samples from the mouth of Villefranche Bay, NW Mediterranean Sea, and in $50 \mu \mathrm{m}$ screened water held in 201 plastic carboys in the laboratory. In various experiments, from 23 to $97 \%$ of the choreotrich assemblage ingested FLB added in tracer amounts ( 2 to $4 \times 10^{5} \mathrm{FLB} \mathrm{ml}^{-1}$ ), with average clearance rates ranging from 14 to $308 \mathrm{nl}$ cell ${ }^{-1} \mathrm{~h}^{-1}$ Very little ingestion of FLB was observed for other types of ciliates, e.g. didinids and hypotrichs, seen in the samples. Specific clearance rates (on the basis of FLB ingested) of individual morphological types of ciliates was on the order of 0.6 to $4 \times 10^{4}$ body volumes $\mathrm{h}^{-1}$ for larger choreotrichs, and up to $2 \times 10^{5}$ body volumes $\mathrm{h}^{-1}$ for the smallest choreotrichs. We estimated that it would be possible for choreotrichs $<15 \mu \mathrm{m}$ in size to grow at a rate of about $0.5 \mathrm{~d}^{-1}$ on an exclusive diet of bacteria at a concentration of $10^{5}$ bacteria $\mathrm{ml}^{-1}$, but that the larger ciliates were obtaining less than $15 \%$ of their food rations as bacteria. These data are the first direct evidence that some pelagic ciliates can be consumers of heterotrophic bacterioplankton in meso- to oligotrophic seawater.
\end{abstract}

\section{INTRODUCTION}

Pelagic ciliates, the majority of which are in Class Spirotrichea, Subclass Choreotrichia (Small \& Lynn 1985), have long been recognized as a major component of microzooplankton in both marine and freshwaters (see reviews by Sorokin 1981, Porter et al. 1985, Sherr et al. 1986). However, their trophic status remains poorly known. The grazing of $>20 \mu \mathrm{m}$ ciliates, particularly tintinnids, on nanoplanktonic ( 2 to $20 \mu \mathrm{m}$ ) phytoplankton has been established as a significant pathway in aquatic food webs (e.g. Rassoulzadegan 1977, Rassoulzadegan \& Etienne 1981, Capriulo \& Carpenter 1983, Verity 1986a, b). Many algivorous ciliates apparently sequester functional chloroplasts from their prey (Blackbourn et al. 1973, McManus \& Fuhrman 1986, Jonsson 1987, Stoecker et al. 1987, Laval-Peuto \& Rassoulzadegan 1988). In addition, recent studies suggest that pelagic ciliates also can consume and grow on picoplanktonic ( $<2 \mu \mathrm{m}$ in size) cells, i.e. tiny eukaryotic algae, cyanobacteria, and bacteria (Johnson et al. 1982, Rivier et al. 1985, Iturriaga \& Mitchell 1986, Sherr \& Sherr 1987, Rassoulzadegan et al. 1988).

Ingestion of bacterioplankton by pelagic choreotri- chous ciliates is at present controversial. Most tested choreotrichs have been shown to clear $<2 \mu \mathrm{m}$ particles with much lower efficiency than they do larger particles (Fenchel 1980a, Rassoulzadegan 1982, Børsheim 1984, Jonsson 1986), due to $>2 \mu \mathrm{m}$ intermembranelle distances (sieve spacing) (Fenchel 1980b, c, Jonsson 1986). However, bacteria have been observed in food vacuoles of field-collected choreotrichs (Gast 1985, Sherr et al. 1986, Rassoulzadegan et al. 1988), and incorporation of radiolabeled bacteria into open ocean pelagic ciliates has been demonstrated (Lessard \& Swift 1985)

Here we present results of a study of the ability of pelagic choreotrichous ciliates from the coastal waters of the NW Mediterranean Sea to ingest bacterioplankton. To do this, we analyzed rates of uptake of fluorescently labeled bacteria (FLB), prepared from natural communities of suspended bacteria, by assemblages of ciliates present in surface water. Initial work using FLB showed that choreotrichous ciliates ingest FLB at higher rates than they do plastic microspheres (Sherr et al. 1987), and that some choreotrichs have much higher clearance rates for bacteria than was previously reported (Sherr \& Sherr 1987). 


\section{MATERIALS AND METHODS}

Surface seawater was collected from Point B, a standard oceanographic station at the mouth of the Bay of Villefranche, France $\left(43^{\circ} 41^{\prime} 10^{\prime \prime} \mathrm{N}, 7^{\circ} 19^{\prime} 0^{\prime \prime} \mathrm{E}\right)$. Point $\mathrm{B}$ water can be considered as oligo-mesotrophic according to classifications in the literature (see Sorokin 1981 for review). Although Sheldon \& Rassoulzadegan (1987) found that for the period March-April, primary production at this site can reach $180 \mu \mathrm{g} \mathrm{C} \mathrm{l}^{-1} \mathrm{~d}^{-1}$, the Bay's average production varies between 5 and $10 \mu \mathrm{g} \mathrm{C}$ $\mathrm{l}^{-1} \mathrm{~d}^{-1}$. The water was collected in $20 \mathrm{l}$ polyethylene carboys and transported directly to the laboratory.

Two types of experiments were carried out: (1) assays of bacterivory for the natural assemblage of pelagic ciliates in subsamples of whole water incubated at in situ temperature $\left(16\right.$ to $\left.19^{\circ} \mathrm{C}\right)$ within 2 to $3 \mathrm{~h}$ of sample collection, and (2) assays of bacterivory for ciliates in 50 um screened seawater held in $1 \mathrm{l}$ glass bottles or in a 201 polyethylene carboy in the laboratory at room temperature $\left(19\right.$ to $\left.20^{\circ} \mathrm{C}\right)$ for periods of 2 to $6 \mathrm{~d}$.

FLB were prepared as described by Sherr et al. (1987), using natural assemblages of bacterioplankton (about $10^{6} \mathrm{ml}^{-1}$, average cell biovolume of $0.06 \mu \mathrm{m}^{3}$ ) present in freshly collected surface seawater prescreened through $0.8 \mu \mathrm{m}$ Nuclepore filters. The bacteria were concentrated using an Amicon ultrafiltration system, Model $\mathrm{CH} 2$, with hollow fiber filters of $0.1 \mu \mathrm{m}$ pore size. FLB were stored frozen, and thawed and briefly sonicated immediately prior to use.

Experiments were conducted in $400 \mathrm{ml}$ Whirl-pak bags, presoaked in $10 \% \mathrm{HCl}$ and copiously rinsed. Seawater sample $(200 \mathrm{ml})$ was added to the bags, which were incubated in a water bath either at in situ temperature (fresh Point B samples) or at room temperature (bottle or carboy samples). A separate $50 \mathrm{ml}$ sample was taken for each experiment and preserved with $2 \%$ final volume alkaline Lugol solution for enumeration of ciliates via the Utermöhl technique. In each experiment, FLB were added to yield concentrations of 2 to $4 \times 10^{5} \mathrm{FLB} \mathrm{ml}^{-1}$, or about 20 to $40 \%$ of the in situ bacterioplankton concentration. Subsamples of $50 \mathrm{ml}$ were taken 10,20 , and 30 min after addition of FLB and fixed with $0.5 \%$ final volume alkaline Lugol solution, to which $3 \%$ final volume borate-buffered formalin was immediately added to decolorize the Lugol stain so that FLB could be visualized within the ciliates. This treatment greatly reduces dissolution of naked ciliates in the formalin (F. Rassoulzadegan unpubl.). Samples of $5 \mathrm{ml}$ taken at the end of the experiment were preserved only with formalin for enumeration of total bacteria and of FLB.

Preserved samples were stained with diamidinophenylindole (DAPI) (Porter \& Feig 1980) and filtered onto $0.8 \mu \mathrm{m}$ Nuclepore-black membrane filters. Filters were mounted onto slides with immersion oil and inspected via epifluorescence microscopy using a Zeiss photomicroscope outfitted with a $50 \mathrm{~W}$ mercury lamp. DAPI-stained ciliates were located using Zeiss filter set 477702 at $100 \times$, and then Zeiss filter set 477709 was used to look for and enumerate FLB within the ciliates at a magnification of $1250 \times$ (Sherr et al. 1987). From 20 to 80 ciliates were inspected in each sample. The linear dimensions of the body of each ciliate were used to compute cell biovolume using equations for a sphere, prolate spheroid, or cone, depending on cell shape.

For those ciliates with ingested FLB, the rate of increase of the average number of FLB ciliate ${ }^{-1}$ was determined from the uptake curve, which was linear during the 30 min incubations (Sherr et al. 1988) and extrapolated to an hourly rate. The FLB ingestion rate was used to derive an average clearance rate of bacteria ( $n$ l ciliate ${ }^{-1} \mathrm{~h}^{-1}$ ) for the portion of the choreotrichous ciliate assemblage with ingested FLB, using the equation: $\mathrm{C}=\mathrm{I} / \mathrm{FLB}$, where $\mathrm{C}=$ clearance rate, $\mathrm{I}=\mathrm{FLB}$ ingested ciliate ${ }^{-1} h^{-1}$, and FLB = concentration of FLB $\mathrm{nl}^{-1}$. In addition, in several experiments we calculated specific clearance rates (body volumes ciliate ${ }^{-1} h^{-1}$ ) for individual morphological types of choreotrichs (based on cell size, shape, and ciliature, and number and shape of nuclei).

Samples for enumeration of bacteria were stained with DAPI (Porter \& Feig 1980), filtered onto $0.2 \mu \mathrm{m}$ Nuclepore black filters, and counted by epifluorescence microscopy at $1250 \times$ as described above.

\section{RESULTS}

Naked choreotrichs composed between 80 and $100 \%$ of the total ciliate assemblage during our study. The smallest cells were about $8 \times 12 \mu \mathrm{m}$ and the largest, $30 \times 60 \mu \mathrm{m}$. Although we were not able to make precise taxonomic identifications, we did find species of Strombidium, Strombilidium, Lohmanniella, and Laboea in samples (see Rassoulzadegan 1977. Rassoulzadegan \& Sheldon 1986). Total ciliate abundance ranged between 1 and 23 ciliates $\mathrm{ml}^{-1}$.

In the experiments with fresh Point B water, bacterioplankton standing stocks were 0.4 to $1.2 \times 10^{6}$ cells $\mathrm{ml}^{-1}$; in the bottle and carbon experiments, bacterial standing stocks ranged from 0.6 to $3.5 \times 10^{6}$ cells $\mathrm{ml}^{-1}$ (Table 1). Average ciliate clearance rates ranged from 14 to $308 \mathrm{nl}$ ciliate ${ }^{-1} \mathrm{~h}^{-1}$, and were generally higher in the carboy experiments (Table 1), perhaps because the species composition of choreotrichs shifted in favor of bacterivores during incubation in the laboratory. Since protozoan grazing rates are negatively related to prey concentration (Fenchel 1980a, Jonsson 1986), the increase of bacterial abundance by addition of FLB 
Table 1. Summary of data on bacterivory by assemblages of naked choreotrichous ciliates in NW Mediterranean coastal waters

\begin{tabular}{|c|c|c|c|c|c|}
\hline $\begin{array}{l}\text { Date: } \\
(1987)\end{array}$ & $\begin{array}{l}\text { Bacterioplankton } \\
\left(10^{6} \mathrm{~m}^{-1}\right)\end{array}$ & $\begin{array}{l}\text { Choreotrichs } \\
\text { (no. } \mathrm{ml}^{-1} \text { ) }\end{array}$ & $\begin{array}{l}\text { Estimated chor } \\
\left(\mathrm{nl} \mathrm{cell} \mathrm{l}^{-1} \mathrm{~h}^{-1}\right)\end{array}$ & $\begin{array}{l}\text { otrich bacterivory } \\
\left.\text { (bacteria cell }{ }^{-1} \mathrm{~h}^{-1}\right)\end{array}$ & $\begin{array}{l}\% \text { of choreotrichs } \\
\text { with ingested FLB }\end{array}$ \\
\hline \multicolumn{6}{|c|}{ (A) Bottle/carboy experiments } \\
\hline $22 \mathrm{Apr}$ & 3.5 & - & 180 & 630 & 94 \\
\hline $23-24 \mathrm{Apr}$ & 2.0 & 2.4 & 285 & 571 & 88 \\
\hline $27-28 \mathrm{Apr}$ & 1.4 & 0.2 & 211 & 295 & 100 \\
\hline $29 \mathrm{Apr}$ & 0.6 & 1.4 & 228 & 137 & 97 \\
\hline 12 Jun & 1.2 & 12 & 130 & 155 & 89 \\
\hline 13 Jun & 1.0 & 14 & 128 & 128 & 100 \\
\hline 14 Jun & 1.0 & 5 & 125 & 125 & 94 \\
\hline 15 Jun & 0.9 & 3 & 198 & 178 & 97 \\
\hline 16 Jun & 0.8 & 4 & 136 & 109 & 100 \\
\hline \multicolumn{6}{|c|}{ (B) Point B water experiments } \\
\hline 1 Jun & 0.8 & 0.9 & 308 & 246 & 88 \\
\hline 2 Jun & 0.6 & 1.0 & 70 & 46 & 94 \\
\hline 9 Jun & 0.4 & 4.3 & 14 & 6 & 26 \\
\hline 10 Jun & 1.0 & 20 & 82 & 82 & 71 \\
\hline 11 Jun & 1.2 & 4 & 127 & 152 & 49 \\
\hline $12 \mathrm{Jun}$ & 1.0 & 2.5 & 92 & 92 & 86 \\
\hline 15 Jun & 1.0 & 8.5 & 83 & 83 & 70 \\
\hline
\end{tabular}

may have resulted in a slight underestimation of the clearance rates. From the clearance rates, we calculated total bacterial ingestion rates of 6 to 630 bacteria ciliate $^{-1} \mathrm{~h}^{-1}$. In all but 2 experiments, $>50 \%$ of naked choreotrichous ciliates ingested FLB. Other types of ciliates seen in the samples, e.g. didinids and hypotrichs, were rarely observed with ingested FLB. These cells were not included in our calculations.

Specific clearance rates were calculated for 22 separate morphological types of ciliates for those experiments in which bacterial standing stocks were about $1 \times 10^{6} \mathrm{ml}^{-1}$. Usually there were from 2 to 5 individual ciliates represented for each morphological type, for which an average biovolume and rate of clearance was calculated. Undoubtedly the 22 morphological types selected represent a lesser number of ciliate species, however we could not be sure that identical species occurred in separate water samples. Body volume for individual morphological types varied from $425 \mathrm{\mu m}^{3}$ to $14200 \mu \mathrm{m}^{3}$. It is possible that fixation may have caused some shrinkage of cell size, as has been reported for heterotrophic flagellates (Børsheim \& Bratbak 1987). However, the proportional amount of shrinkage would be expected to be similar across the spectrum of sizes of naked choreotrichs, and this should not seriously affect the relationship between cell size and clearance rate. A logarithmic plot of specific clearance vs body volume (Fig. 1) showed a general negative relationship between the two. The highest specific clearance rates, 1.2 to $2.4 \times 10^{5}$ body volumes $h^{-1}$, were found for ciliates with cell volumes of less than $1800 \mu \mathrm{m}^{3}$.

Based on the specific clearance rates of choreotrichous ciliates at the in situ bacterioplankton abun-

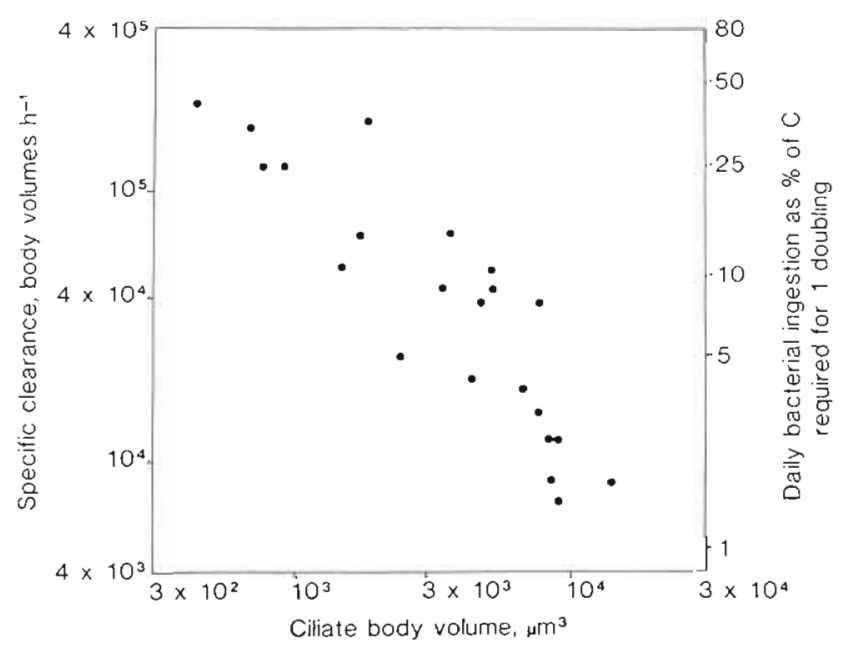

Fig. 1. Logarithmic plot of cell-specific clearance rates as a function of ciliate body volume determined via uptake of FLB by discrete morphological forms within choreotrichous ciliate assemblages in surface waters of the NW Mediterranean Sea. Estimated daily ingestion of bacteria as the percent of calculated carbon required for one cell doubling, at a bacterial concentration of $1 \times 10^{6}$ cells $\mathrm{ml}^{-1}$, is shown on the right vertical axis

dance of $1 \times 10^{6}$ bacteria $\mathrm{ml}^{-1}$, we estimated the bacterial ingestion of individual ciliate types in terms of food requirements for growth. We made the following assumptions: a ciliate growth efficiency of $40 \%$ (Jonsson 1986, Verity 1986a); a ciliate carbon content of $0.1 \mathrm{pg} \mathrm{C} \mu \mathrm{m}^{-3}$ (Sherr et al. 1986); an average size for in situ bacterioplankton of $0.06 \mu^{3}$ (Rassoulzadegan unpubl.); and an average carbon content of bacterioplankton of $0.35 \mathrm{pg} \mathrm{C} \mathrm{mm}^{-3}$ (Bjørnsen 1986, Lee \& 
Fuhrman 1987). Using these assumptions, the specific clearance values were converted to daily bacterial ingestion as percent of the total carbon required for one cell doubling (right vertical axis in Fig. 1). For ciliates with specific clearance rates greater than $10^{5} \mathrm{~h}^{-1}$, daily bacterial ingestion could provide from 25 to $50 \%$ of their food requirements for one doubling. For the other ciliates analysed, daily bacterial uptake would provide less than $15 \%$ of food requirements for growth (Fig. 1).

\section{DISCUSSION}

The current theory of protozoan bacterivory in the sea holds that pelagic ciliates cannot be primarily bacterivorous except under special circumstances: dense patches of bacteria or very rich estuarine water (Fenchel 1984, Sieburth 1984). Experimental studies carried out with pelagic ciliates have generally supported this idea (e.g. Fenchel 1980b, Rassoulzadegan 1982, Børsheim 1984, Gast 1985, Jonsson 1986). However, contrary evidence has been presented that (1) a 20 to $30 \mu \mathrm{m}$ choreotrich, Strombidium sulcatum, could be grown on bacteria at concentrations less than $10^{6}$ bacteria $\mathrm{ml}^{-1}$ (Rivier et al. 1985), and (2) based on FLB uptake, pelagic ciliates in waters of a salt marsh estuary grazed in situ bacteria at rates of 140 to $270 \mathrm{nl} \mathrm{h}^{-1}$, corresponding to cell-specific clearance rates of $4 \times 10^{4} \mathrm{~h}^{-1}$ to $6.8 \times 10^{5} \mathrm{~h}^{-1}$ (Sherr \& Sherr 1987).

These data are likely not in conflict. An important factor is choice of experimental organisms. In the earlier studies, the investigators experimented with either hymenostome ciliates such as Uronema, or medium to large polyhymenophoran ciliates which were primarily algivorous. The latter 2 studies, however, addressed the physiological capabilities of in situ pelagic ciliates $<20$ to $30 \mu \mathrm{m}$ in size (Sherr \& Sherr 1987) and of a choreotrich, Strombidium sulcatum, which could be cultured on bacteria alone (Rivier et al. 1985).

Ciliates capable of filtering bacterial-sized particles are characterized by very small $(<2 \mu \mathrm{m})$ intermembranelle distances within the oral ciliature, which, based on hydrodynamic considerations, leads to absolute clearance rates for bacterivorous ciliates which are much lower than those found for ciliates adapted to grazing on phytoplankton (Fenchel 1980a, c). Herbivorous ciliates typically filter algal cells at rates of 2000 to $26000 \mathrm{nlh}^{-1}$ (summarized by Jonsson 1986), while rates for ciliate bacterivory are on the order of 40 to $300 \mathrm{nl} \mathrm{h}^{-1}$ (Fenchel 1980b, Børsheim 1984, Sherr \& Sherr 1987)

In the present study, we found rates of bacterivory to be similar for choreotrichs over a wide range of size. We suspect that for small ciliates, low filtering rates are due to their closely spaced membranelles, while the coarser filtering apparatus of medium to large ciliates makes them rather inefficient bacterivores. For larger, mainly algivorous choreotrichs, the apparent clearance rate based on bacterial ingestion should thus be much lower than the actual filtration rate. It is likely that bacterivory in the algivorous species was a by-product of their grazing on phytoplankton.

Ciliates other than choreotrichs found in the samples were rarely seen with ingested FLB. The feeding habits of such species may have precluded significant uptake of freely suspended picoplankton. For example, Didinium spp. usually prey on other ciliates (Antipa et al. 1983) and Euplotes spp. are specialized for grazing on particle surfaces (Albright et al. 1987).

Bacterivorous ciliates are not necessarily excluded from a pelagic existence because of low absolute filtering rates. A $15 \mu \mathrm{m}$ ciliate grazing bacteria at $300 \mathrm{nl} \mathrm{h}^{-1}$ will have a specific clearance rate of $1.7 \times 10^{5}$ body volumes $h^{-1}$, comparable to the specific clearance rates of larger ciliates grazing algae (Jonsson 1986). In addition, it appears that bacteria are more carbon-rich per unit biovolume than previously thought. Recent estimates of carbon content of in situ marine bacterioplankton have suggested values of 0.35 and $0.38 \mathrm{pgC}$ $\mu^{-3}$ of bacterial biovolume (Bjørnsen 1986, Lee \& Fuhrman 1987). We used a value of $0.35 \mathrm{pg} \mathrm{C} \mathrm{um}^{-3}$ for bacterial carbon content in our calculations, based on the 2 papers cited above and on the fact that this is a median value for various recent estimates which range from $0.11 \mathrm{pg} \mathrm{C} \mathrm{m}^{-3}$ (Heldal et al. 1985, Nagata 1986) to $0.56 \mathrm{pg} \mathrm{C} \mathrm{mm}^{-3}$ (Bratbak 1985). If in situ bacterioplankton are several-fold richer in carbon than are their ciliate predators, ciliates would need to graze concommitantly less bacterial biovolume to meet their food requirements.

A secondary factor may also in part explain discrepancies between our bacterial grazing rates and those measured using uptake of latex particles (Børsheim 1984, Jonsson 1986, Stoecker 1988). Emerging natural history information about filter-feeding ciliates indicates that these phagotrophic protozoa are not simple mechanistic feeders as previously supposed. Filterfeeding ciliates may be chemosensory to their prey (Antipa et al. 1983, Capriulo et al. 1986, Verity 1988), show active selection and rejection of potential food items (Stoecker et al. 1981, Stoecker 1988, Taniguchi \& Takeda 1988), and are capable of differential selective uptake of free or particle-attached bacteria (Albright et al. 1987). We have found experimentally that both estuarine choreotrichous ciliates (Sherr et al. 1987) and Strombidium sulcatum (E. Sherr unpubl.) ingest FLB at rates several-fold higher than they do latex microspheres of equivalent size. Thus rates of bacterivory obtained using inert latex particles may be underestimates of the true grazing rate on bacteria. 
The question of whether ciliates also show discrimination for or against FLB compared to untreated bacteria is another matter. We have recently carried out a series of experiments designed to compare relative uptake of FLB and live bacteria, using mixed species cultures of bacterivorous flagellates and an isolated pelagic choreotrich, Strobilidium conicum. In these experiments, we found no significant differences in long-term (18 to 24 h) percent decrease of FLB or of live bacteria which were prevented from dividing by addition of prokaryotic inhibitor, when grazed by a mixture of flagellates and $S$. conicum (Sherr et al. 1989).

In the present study, we have demonstrated bacterial ingestion by a large fraction of the assemblage of pelagic choreotrichous ciliates present in surface coastal waters of the NW Mediterranean. In most of our experiments, the total abundance of bacterioplankton was equal to, or less than, $10^{6}$ cells $\mathrm{ml}^{-1}$. Only during the end of the spring phytoplankton bloom, in May, were bacterial abundances much above this value (Table 1). For the smallest ciliates in our samples, daily bacterial ingestion at $10^{6}$ bacteria $\mathrm{ml}^{-1}$ could satisfy up to $50 \%$ of food requirements for 1 doubling (Fig, 1). These ciliates could either be growing in bacteria at a rate of $0.5 \mathrm{~d}^{-1}$, or supplementing their diet with other picoplanktonic and small nanoplanktonic cells (Rassoulzadegan et al. 1988) to sustain higher growth rates. Bacteria were of lesser importance in the diet of larger ciliates in our study, as suggested previously by Rassoulzadegan et al. (1988). However, if they were to encounter denser concentrations of bacteria, some of the pelagic choreotrichs might be able to support reasonable rates of growth on a solely bacterial diet, as has already been shown for Strombidium sulcatum in laboratory culture (Rivier et al. 1985).

Acknowledgements. We thank Lea Kneib and Eileen Hedick for preparation of the table and the figure, and anonymous reviewers for their comments on the manuscript. This work was supported by NATO Grant No. 86/676, by NSF Grant No. OCE-8700456 (to B. and E. Sherr), by UA 716 (Ecologie Microbienne Planktonique) and GRECO 34/P4/MEDIPRO (Operation No. 4 RT) of the French C.N.R.S. to F. Rassoulzadegan, and by grants from the Sapelo Island Research Foundation. Contribution no. 633 of the University of Georgia Marine Institute.

\section{LITERATURE CITED}

Albright, L. J., Sherr, E. B., Sherr, B. F., Fallon, R. D. (1987). Grazing of ciliated protozoa on free and particle-attached bacteria. Mar. Ecol. Prog. Ser. 38: 125-129

Antipa, G. A., Martin, K., Rintz, M. T (1983). A note on the possible ecological significance of chemotaxis in certain ciliated protozoa. J. Protozool. 30: 55-57

Bjømsen, P. K. (1986). Automatic determination of bacterioplankton biomass by image analysis. Appl. environ. Microbiol. 51: 1199-1204
Blackbourn, D. J., Taylor, F. J. R., Blackbourn, J. (1973). Foreign organelle retention by ciliates. J. Protozool. 20: 286-288

Børsheim, K. Y. (1984). Clearance rates of bacteria-sized particles by freshwater ciliates, measured with mono-disperse fluorescent latex beads. Oecologia (Berl.) 63: 286-288

Borsheim, K. Y., Bratbak, G. (1987). Cell volume to cell carbon conversion factors for a bacterivorous Monas sp. enriched from seawater Mar Ecol. Prog. Ser. 36: 171-175

Bratbak, G. (1985). Bacterial biovolume and biomass estimation. Appl environ. Microbiol. 49: 1488-1493

Capriulo, G. M., Carpenter, E. J. (1983). Abundance, species composition, and feeding impact of tintinnid micro-zooplankton in central Long Island Sound. Mar. Ecol. Prog. Ser 10: $277-288$

Capriulo, G. M., Tavernas, J., Gold, K. (1986). Ciliate feeding: effect of food presence or absence on occurrence of striae in tintinnids. Mar. Ecol. Prog. Ser. 30: 145-158

Fenchel, T (1980a). Suspension feeding in ciliated protozoa: functional response and particle size selection. Microb. Ecol. 6: 1-11

Fenchel, $T$ (1980b). Suspension feeding in ciliated protozoa: feeding rates and their ecological significance. Microb. Ecol. 6: 13-25

Fenchel, T (1980c). Suspension feeding in ciliated protozoa: structure and function of feeding organelles. Arch. Protistenk. 123: $239-260$

Fenchel, T (1984). Suspended marine bacteria as a food source. In: Fasham, M. J. R. (ed.) Flows of energy and materials in marine ecosystems. Plenum Press, New York, p. 301-316

Gast, V. (1985). Bacteria as a food source for microzooplankton in the Schlei Fjord and Baltic Sea with special reference to ciliates. Mar Ecol. Prog. Ser 22: 107-120

Heldal, M. Norland, S., Tumyr, I. (1985). X-ray microanalytical method for measurement of dry matter and elemental content of individual bacteria. Appl. environ. Microbiol. 50: 1251-1257

Iturriaga, R., Mitchell, B. G. (1986), Chroococcoid cyanobacteria: a significant component in the food web dynamics of the open sea. Mar. Ecol. Prog. Ser. 28: 291-297

Johnson, P. W., Xu, H.-S., Sieburth, J. McN. (1982). The utilization of chroococcoid cyanobacteria by marine protozooplankters but not by calanoid copepods. Annls Inst. océanogr., Paris 58 (S.): 297-308

Jonsson, P. R. (1986). Particle size selection, feeding rates and growth dynamics of marine planktonic oligotrichous ciliates (Ciliophora: Oligotrichina). Mar. Ecol. Prog. Ser. 33: 265-277

Jonsson, P. R. (1987). Photosynthetic assimilation of inorganic carbon in marine oligotrich ciliates (Ciliophora, Oligotrichina). Mar Microb. Food Webs 2: 55-68

Laval-Peuto, M., Rassoulzadegan, F. (1988). Autofluorescence of marine planktonic oligotrichina and other ciliates. Hydrabiologia 159: 99-110

Lee, S., Fuhrman, J. D. (1987). Relationships between biovolume and biomass of naturally derived marine bacterioplankton. Appl. environ. Microbiol. 53: 1298-1303

Lessard, E. J., Swift, E. (1985). Species-specific grazing rates of heterotrophic dinoflagellates in oceanic waters, measured with a dual-label radioisotope technique. Mar Biol. 87: $289-296$

McManus, G. B., Fuhrman, J. A. (1986). Photosynthetic pigments in the ciliate Laboea strobila from Long Island Sound, USA. J. Plankton Res. 8: 317-327

Nagata, T (1986). Carbon and nitrogen content of natural planktonic bacteria. Appl. environ. Microbiol. 52: 28-32 
Porter, K. G., Feig, Y. S. (1980). The use of DAPI for identifying and counting aquatic microflora. Limnol. Oceanogr 25: 943-948

Porter, K. G., Sherr, E. B., Sherr, B. F., Pace, M., Sanders, R. W (1985). Protozoa in planktonic food webs. J. Protozool. 32 409-415

Rassoulzadegan, F. (1977). Annual variation of pelagic ciliates from the North-western Mediterranean Sea. Annls Inst océanogr., Paris 53: 125-134

Rassoulzadegan, F. (1982). Dependence of grazing rate, gross growth efficiency, and food size range on temperature in a pelagic oligotrichous ciliate Lohmanniella spiralis Leeg., fed on naturally occurring particulate matter. Annls Inst. océanogr., Paris 58: 177-184

Rassoulzadegan, F., Etienne, M. (1981). Grazing rate of the tintinnid Stenosemella ventricosa (Clap. and Lachm.) Jorg., on the spectrum of the naturally occurring particulate matter from a Mediterranean neritic area. Lirnnol. Oceanogr. 26: 258-270

Rassoulzadegan, F., Laval-Peuto, M., Sheldon, R. W. (1988). Partition of the food ration of marine ciliates between picoand nanoplankton. Hydrobiologia 159: 75-88

Rassoulzadegan, F., Sheldon, R. W. (1986). Predator-prey interactions of nanozooplankton and bacteria in an oligotrophic marine environment. Limnol. Oceanogr 31 1010-1021

Rivier, A., Brownlee, D. C., Sheldon, R. W., Rassoulzadegan, F. (1985). Growth of microzooplankton: a comparative study of bacterivorous zooflagellates and ciliates. Mar. Microb. Food Webs 1: 36-51

Sheldon, R. W., Rassoulzadegan, F. (1987). A method for measuring plankton production by particle counting. Mar. Microb. Food Webs 2: 29-44

Sherr, B. F., Sherr, E. B., Fallon, R. D. (1987). Use of monodispersed, fluorescently labeled bacteria to estimate in situ protozoan bacterivory. Appl. environ. Microbiol. 53 958-965

Sherr, B. F., Sherr, E. B., Pedros-Alio, C. (1989). Simultaneous measurement of bacterioplankton production and protozoan bacterivory in estuarine water. Mar. Ecol. Prog. Ser 54: 209-219

Sherr, B. F., Sherr, E. B., Rassoulzadegan, F. (1988). Rates of

This article was presented by Dr M. Levandowsky, New York, USA digestion of bacteria by marine phagotrophic protozoa: temperature dependence. Appl. environ. Microbiol. 54: $1091-1095$

Sherr, E. B., Sherr, B. F. (1987). High rates of consumption of bacteria by pelagic ciliates. Nature, Lond. 325: 710-711

Sherr, E. B., Sherr, B. F., Fallon, R. D., Newell, S. Y (1986). Small aloricate ciliates as a major component of the marine heterotrophic nanoplankton. Limnol. Oceanogr. 31 : 177-183

Sieburth, J. McN. (1984). Protozoan bacterivory in pelagic marine waters. In: Hobbie, J. E., Williams, P. J. leB. (eds.) Heterotrophic activity in the sea. Plenum Press, New York, p. $405-444$

Small, E. B., Lynn, D. H. (1985). Phylum Ciliophora. In: Lee, J. J., Hutner, S. H., Boviee, E. C. (eds.) Illustrated guide to the protozoa. Soc. Protozool. Special Pub., Allen Press, Lawrence, Kansas, p. 393-575

Sorokin, Yu. I. (1981). Microheterotrophic organisms in marine ecosystems. In: Longhurst, A. R. (ed.) Analysis of marine ecosystems. Academic Press, New York, p. 293-342

Stoecker, D. K. (1988). Are marine planktonic ciliates suspension-feeders? J. Protozool. 35: 252-255

Stoecker, D., Guillard, R. R., Kavee, R. M. (1981). Selective predation by Favella ehrenbergi (Tintinnia) on and among dinoflagellates. Biol. Bull. mar. biol. Lab., Woods Hole 160: 136-145

Stoecker, D. K., Michaels, A. E., Davis, L. H. (1987). Large proportion of marine planktonic ciliates found to contain functional chloroplasts. Nature, Lond. 326: 790-792

Taniguchi, A., Takeda, Y. (1988). Feeding rate and behavior of the tintinnid ciliate Favella taraikaensis observed with a high speed VTR system. Mar. Microb. Food Webs 3: 21-34

Verity, P. G. (1986a). Growth rates of natural tintinnid populations in Narragansett Bay. Mar. Ecol. Prog. Ser 29: $117-126$

Verity, P. G. (1986b). Grazing of phototrophic nanoplankton by microzooplankton in Narragansett Bay. Mar. Ecol. Prog. Ser. 29: 105-115

Verity, P. G. (1988). Chemosensory behavior in planktonic ciliates. Zooplankton Behavior Symposium. Bull mar Sci. 43: $772-782$

Manuscript first received: September 26, 1988

Revised version accepted: May 3, 1989 